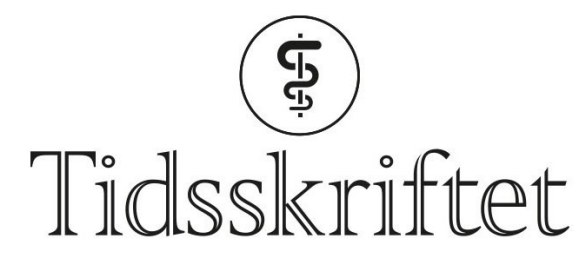

DEN NORSKE LEGEFORENING

\title{
Børre Olsen
}

MINNEORD

BÅRD I. FREBERG

HARALD OMLAND

EDVIND WOLD

ARVE RENNESUND

PER WILLIAM BRATLIE-JENSEN

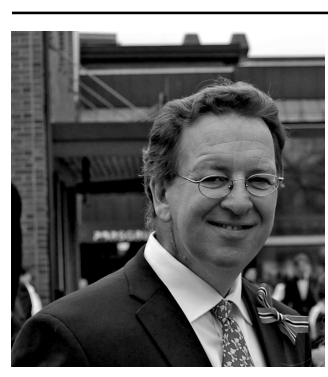

Børre Olsen døde 23. mai 2019, nær 58 år gammel.

Børre vokste opp i Drammen med en hjemmeværende mor og en far som var sveiser. Han var stolt av sin bakgrunn og forble alltid drammensgutt. I sine yngre dager spilte han sjakk og trente styrkeløft, og ble juniornorgesmester i benkpress. Han var også en ivrig seiler og deltok i mange norgesmesterskap i Knarr-klassen. Han elsket å tilbringe tid på hytta i Sande i Vestfold - barndommens paradis hvor mang en makrell var tatt på kroken. Noen lakseturer i Drammenselva ble det også tid til. Børre var i tillegg en glimrende forteller og diktoppleser, og hans humor og rungende latter var meget smittsom.

Etter endt studium ved Universitetet i Oslo i 1989, turnustjeneste og offiserskurs var han i sin verneplikt skipslege på minerydder.

Børre begynte som assistentlege ved Kirurgisk avdeling ved Sykehuset Telemark i 1992. Her ble han godkjent spesialist i generell kirurgi og senere spesialist i urologi etter arbeid ved Urologisk seksjon og ved Rikshospitalet. Senere ble han ansatt som seksjonsoverlege ved Urologisk seksjon ved Sykehuset Telemark. Denne oppgaven utførte han på en utmerket måte. Under hans ledelse ble denne seksjonen faglig god og selvstendig. Sammen med fagmiljøet i urologi ved sykehuset fikk han gjennomført at sykehuset skulle kjøpe operasjonsrobot. Denne tok sykehuset i bruk i 2007, som andre sykehus i Norge (etter Radiumhospitalet). Dette førte til at Urologisk seksjon fikk henvist pasienter til radikal 
prostatektomi fra hele Norge. Børre Olsen var med i operasjonsteamet fra starten.

Børre var svært opptatt av at pasientene skulle få den beste behandlingen. Han var en faglig sterk og dedikert praktiker. Som leder var han ikke den som snakket for mye, men når han først tok ordet, ble han lyttet til.

De siste 10-12 årene hadde han to alvorlige sykdomsperioder. Han var borte fra fagmiljøet i lengre perioder, men hans stahet førte han alltid tilbake i jobb. Etter siste periode for 3-4 år siden fikk han mye plager etter behandlingen. Han måtte gå ut av klinisk arbeid, men hadde en administrativ deltidsstilling. I denne var han i jobb til få uker før han døde.

Børre var raus og satt alltid den andre først, enten det var pasienten eller hans venner og kollegaer. Han er dypt savnet.

Våre tanker går til hans kone Hanne og datter Sarah.

Publisert: 23. september 2019. Tidsskr Nor Legeforen. DOI: 10.4045/tidsskr.19.0483

(C) Tidsskrift for Den norske legeforening 2020. Lastet ned fra tidsskriftet.no 